\title{
ANALISIS PENERAPAN PAJAK PENGHASILAN FINAL PASAL 4 AYAT 2 ATAS JASA KONSTRUKSI PADA PT. REALITA TIMUR PERKASA
}

\author{
Hillary S.P Ratuela ${ }^{1}$, Jullie J. Sondakh ${ }^{2}$, Anneke Wangkar ${ }^{3}$ \\ ${ }^{1,2,3}$ Fakultas Ekonomi dan Bisnis, Jurusan Akuntansi, Universitas Sam Ratulangi, Jl.Kampus Bahu, Manado, \\ 95115, Indonesia \\ E-mail : hillaryspratuela@yahoo.com
}

\begin{abstract}
One source of domestic development financing is through the receipt of the tax sector which is one of the largest sources of revenue or income of the state. One type of tax is the Final Income Tax. Of the many taxpayers, construction services is one of the taxpayer, and one of the objects of the Final Income Tax. The purpose of this study is to analyze the implementation of the final income tax article 4 paragraph 2 on construction services at PT. Realita Timur Perkasa in this case concerning the calculation, cutting, deposit, and reporting of Final Income Tax Article 4 paragraph 2. The analytical method used is decriptive method. Based on the results of research obtained shows that the income tax rate Article 4 paragraph 2 that is charged by PT Realita Timur Perkasa that is 3\%. For the implementation of tax obligations concerning tax reporting not yet in accordance with applicable taxation provisions. Should pay more attention to the provisions of taxation in this case the calculation, cutting, depositing, and reporting Income Tax Article 4 paragraph 2 of the construction services in order to be executed in accordance with applicable tax provisions.

Keywords: Final Income Tax, Construction Services.
\end{abstract}

\section{PENDAHULUAN}

Salah satu jenis pajak yang dikenal di Indonesia ialah Pajak Penghasilan (PPh). Dari sekian banyak wajib pajak, jasa konstruksi merupakan salah satu wajib pajak sehingga wajib untuk melaksanakan kewajiban perpajakan guna menunjang pembangunan demi peningkatan sarana dan prasarana. Untuk peraturan pajak atas usaha jasa konstruksi ini memiliki aturan khusus, yaitu pengenaan pajaknya berbeda dengan pengenaan pajak yang biasa dikenakan pada wajib pajak badan lainnya. Peraturan yang mengatur mengenai pajak penghasilan atas usaha jasa konstruksi ini dibahas lebih detail dalam Peraturan Menteri Keuangan (PMK) Nomor 153/PMK.03/2009 yang merupakan perubahan dari PMK Nomor 187/PMK.03/2008 yang didalamnya menjelaskan bahwa setiap penghasilan yang akan diterima wajib pajak dari usaha jasa konstruksi dikenakan pajak dan penghasilannya dipotong pajak yang bersifat final menurut Undang-Undang Perpajakan Nomor 36 Tahun 2008 Pasal 4 ayat 2.

Usaha jasa konstruksi meliputi tiga kelompok yaitu jasa perencanaan konstruksi, jasa pelaksana konstruksi, dan jasa pengawasan konstruksi. Tarif yang dikenakan untuk pajak penghasilan atas usaha jasa konstruksi ini berbeda-beda, dilihat menurut kepemilikan sertifikat badan usaha dan masa berlakunya sertifikat tersebut. Untuk jasa pelaksana konstruksi, tarifnya ditentukan berdasarkan tingkatan dari kewenangan kontraktor. Tarif $\mathrm{PPh}$ final pasal 4 ayat 2 atas jasa konstruksi yaitu $4 \%$ untuk jasa perencanaan konstruksi apabila seorang kontraktor memiliki sertifikat badan usaha, dan $6 \%$ bagi kontraktor yang tidak memiliki sertifikat badan usaha. Untuk jasa pelaksanaan konstruksi yang memiliki sertifikat badan usaha yang masuk dalam kategori usaha kecil (tingkatan 1,2,3,4) dikenakan tarif $2 \%$, sedangkan untuk kontraktor yang memiliki sertifikat badan usaha yang masuk dalam kategori usaha menengah dan besar (tingkatan 5,6,7) dan apabila kontraktor tidak memiliki sertifikat badan usaha maka tarif yang dikenakan yaitu sebesar $4 \%$. Untuk jasa pengawasan konstruksi 
dikenakan tarif $4 \%$ bagi kontraktor yang memiliki sertifikat badan usaha dan $6 \%$ bagi kontraktor yang tidak memiliki sertifikat badan usaha. Nilai pajak penghasilan bisa dihitung menggunakan DPP (Dasar Pengenaan Pajak) dari usaha jasa konstruksi yang dikalikan dengan tarif pajak yang akan dikenakan.

Dalam penelitian ini PT. Realita Timur Perkasa bergerak sebagai pelaksana usaha jasa konstruksi yang memiliki Sertifikat Badan Usaha (SBU) dan didalamnya menunjukkan bahwa PT. Realita Timur Perkasa termasuk dalam kualifikasi usaha menengah dan besar, dan dikenakan tarif PPh final pasal 4 ayat 2 sebesar 3\%. Namun dalam melakukan pelaporan $\mathrm{PPh}$ Pasal 4 ayat 2 PT. Realita Timur Perkasa terkadang masih mengalami kendala atau permasalahan yang disebabkan oleh satker pihak pembeli atau pengguna jasa yaitu sering adanya keterlambatan kelengkapan dokumen-dokumen untuk menjadi lampiran pada saat pelaporan pajak, hal ini berdampak bagi PT. Realita Timur Perkasa sehingga terjadi keterlambatan pada saat akan melakukan pelaporan ke Kantor Pelayanan Pajak. Penelitian ini bertujuan untuk menganalisis penerapan pajak penghasilan final pasal 4 ayat 2 atas jasa konstruksi pada PT. Realita Timur Perkasa dalam hal ini mengenai perhitungan, pemotongan, penyetoran, dan pelaporan PPh Final Pasal 4 ayat 2.

\section{TINJAUAN PUSTAKA}

Konsep Akuntansi. Yang dimaksud dengan akuntansi yaitu proses untuk mencatatat, mengklasifikasi dan mengikhtisarkan dengan cara signifikan di setiap transaksi dan perihal yang sebagian diantaranya mempunyai sifat keuangan, selanjutnya melakukan penginterpretasian hasil (Watung, 2016). Hendra (2014), menyatakan akuntansi merupakan suatu pengetahuan yang mempunyai kepentingan dalam masalah penyediaan, pengesahan, proses mencatat, mengklasifikasi, meringkas, menganalisis, penginterpretasian hasil dengan cara sistematik untuk informasi yang bisa dipercayai dan berguna untuk setiap transaksi dan perihal yang mempunyai sifat keuangan yang diperlukan pada saat mengolah dan mengoperasikan suatu usaha dan untuk dasar dalam menyusun laporan yang akan disampaikan demi mempertanggungjawabkan urusan keuangan dan lain sebagainya.

\section{Konsep Perpajakan}

Definisi dan Unsur Pajak. Menurut Prof. Dr. Rochmat Soemitro, S.H, yang tedapat dalam Mardiasmo (2018: 3) pajak merupakan suatu iuran dari rakyat untuk kas suatu negara yang berdasarkan undang-undang (bisa dipaksakan) dan tidak mendapatkan jasa timbal balik yang bisa ditunjukkan dan digunakan dalam pembayaran pengeluaran yang bermanfaat bagi masyarakat pada umumnya. Dari definisi yang sudah disebutkan di atas, dapat dikatakan bahwa pajak mempunyai unsur-unsur yaitu:

1. Iuran rakyat kepada negara.

2. Menurut undang-undang.

3. Tanpa jasa timbal atau kontraprestasi dari negara yang secara langsung dapat ditunjuk.

4. Dipakai untuk membiayai rumah tangga negara, seperti pengeluaran-pengeluaran yang bermanfaat bagi masyarakat luas.

Fungsi Pajak. Mardiasmo (2018:4), fungsi pajak terbagi 2 (dua) yaitu:

1. Fungsi Anggaran, yaitu pajak mempunyai fungsi sebagai suatu sumber dana pemerintah dalam membiayai pengeluaran-pengeluaran yang bermanfaat bagi masyarakat.

2. Fungsi Mengatur, yaitu pajak sebagai alat dalam mengatur maupun melakukan keputusan pemerintah dalam hal perekonomian dan sosial.

Pembedaan dan Pembagian Jenis Pajak. Mardiasmo (2018:7), pajak umumnya dikategorikan antara lain sebagai berikut:

1. Menurut golongannya, yaitu pajak langsung dan pajak tidak langsung.

2. Menurut sifatnya, yaitu pajak subyektif dan pajak obyektif. 
3. Menurut lembaga pemungutnya, yaitu pajak pusat dan pajak daerah.

Sistem Pemungutan Pajak. Mardiasmo (2018:9), sistem pemungutan pajak dapat dibagi menjadi 3 yaitu sebagai berikut: Official Assessment System, Self Assessment System, dan Witholding System

Akuntansi Perpajakan. Akuntansi pajak merupakan suatu bidang dalam akuntansi yang berhubungan dengan perhitungan pajak berdasarkan peraturan perpajakan beserta pelaksanaannya (Hakim, 2015). Sedangkan menurut Agoes dan Trisnawati (2009:7) akuntansi pajak merupakan penerapan akuntansi yang sesuai dengan peraturan pajak. Salah satu bagian dari akuntansi komersial yaitu akuntansi perpajakan. Berbeda dengan akuntansi komersial yang memiliki standar, Akuntansi perpajakan sendiri tidak memiliki standar seperti yang telah ditetapkan dalam SAK (Standar Akuntansi Keuangan). Akuntansi pajak hanya digunakan pada saat melakukan pencatatan transaksi yang berkaitan dengan perpajakan. Sekarang wajib pajak bisa dengan mudah dalam membuat Surat Pemberitahuan (SPT) karena sudah adanya akuntansi pajak.

\section{Pajak Penghasilan Final Pasal 4 ayat 2}

Pengertian Pajak Penghasilan Final Pasal 4 ayat 2. Menurut Undang-Undang No. 36 tahun 2008 tentang Pajak Penghasilan, pasal 4 Ayat 2 menyebutkan beberapa objek dimana penghasilannya dikenakan pajak final, yaitu: penghasilan dari bunga deposito dan tabungan yang lain, bunga obligasi, surat utang negara, pembayaran bunga simpanan dari koperasi kepada orang pribadi anggota koperasi, hadiah undian, persetujuan atas penjualan dan pembelian saham dan sekuritas yang lain, persetujuan jual beli derivatif yang diperdagangkan di bursa, persetujuan jual beli saham atau penyertaan modalnya dialihkan pada perusahaan pasangannya dan diterima oleh perusahaan modal ventura, persetujuan jual beli atas pengalihan harta atas tanah dan/atau bangunan, penghasilan dari usaha jasa konstruksi, usaha real estate, dan persewaan tanah dan/atau bangunan; dan penghasilan yang lain sesuai dengan atau menurut peraturan pemerintah. Pajak penghasilan bersifat final artinya bahwa penghasilan tersebut sudah tidak perlu digabungkan dengan penghasilan-penghasilan yang lain dalam menghitung pajak terutang dan pajak penghasilan tersebut yang dikenakan tidak bisa dikreditkan. Pemotongan bersifat final artinya bahwa penghasilan tersebut tidak perlu digabung dengan penghasilan lainnya dalam perhitungan pajak penghasilan terutang dan pajak penghasilan yang dikenakan tidak dapat dikreditkan. Dengan demikian maka penghasilan yang telah dikenakan pajak penghasilan final ini tidak akan dihitung lagi pajak penghasilannya pada SPT tahunan dengan penghasilan lain yang non final.

Pajak Penghasilan Final Pasal 4 Ayat 2 atas Jasa Konstruksi. Berdasarkan hukum yang mengatur tentang pajak atas usaha jasa konstruksi tercantum dalam Peraturan Pemerintah (PP) Nomor 40 tahun 2009 yang merupakan perubahan dari Peraturan Pemerintah (PP) Nomor 51 tahun 2008, tentang Pajak Penghasilan atas Penghasilan dari Usaha Jasa Konstruksi dan PMK (Peraturan Menteri Keuangan) Republik Indonesia Nomor 187/PMK.03/2008, tentang Tata Cara Pemotongan, Penyetoran, Pelaporan, dan Penatausahaan Pajak Penghasilan atas Penghasilan dari Usaha Jasa Konstruksi. Berdasarkan Undang-Undang Perpajakan No. 36 tahun 2008 tentang Pajak Penghasilan pasal 4 ayat 2, usaha jasa konstruksi ini merupakan objek pajak dimana penghasilannya dikenakan pajak bersifat final.

\section{Perhitungan PPh Pasal 4 ayat 2 atas Jasa Konstruksi}

Dasar Pengenaan PPh Pasal 4 Ayat 2 atas Jasa Konstruksi. Dasar Pengenaan Pajak Penghasilan Pasal 4 ayat 2 atas Jasa Konstruksi adalah sebagai berikut:

1. Jika dipotong oleh pemotong pajak dalam hal ini bendahara pemotong yaitu jumlah pembayaran (tidak termasuk PPN). 
2. Jika penyedia jasa menyetor sendiri dalam hal ini perusahaan jasa konstruksi, dasar pengenaan pajaknya yaitu jumlah penerimaan pembayaran (tidak termasuk PPN).

Tarif PPh Pasal 4 ayat 2 atas Jasa Konstruksi. Tarif yang dikenakan untuk pajak penghasilan atas usaha jasa konstruksi ini berbeda-beda, dilihat menurut kepemilikan sertifikat badan usaha dan masa berlakunya sertifikat tersebut. Untuk jasa pelaksana konstruksi, tarifnya ditentukan berdasarkan tingkatan dari kewenangan kontraktor. Tarif pajak penghasilan final pasal 4 ayat 2 atas jasa konstruksi yaitu sebesar $4 \%$ untuk jasa perencanaan konstruksi apabila seorang kontraktor memiliki sertifikat badan usaha, dan 6\% bagi kontraktor yang tidak memiliki sertifikat badan usaha. Untuk jasa pelaksanaan konstruksi apabila kontraktor tersebut memiliki sertifikat badan usaha dan masuk dalam kategori usaha kecil (tingkatan 1,2,3,4) maka dikenakan tarif sebesar 2\%, sedangkan untuk kontraktor yang memiliki sertifikat badan usaha yang masuk dalam kategori usaha menengah dan besar (tingkatan 5,6,7) dan kontraktor tersebut tidak memiliki sertifikat badan usaha maka tarif yang dikenakan yaitu sebesar $4 \%$. Untuk jasa pengawasan konstruksi dikenakan tarif $4 \%$ bagi kontraktor yang memiliki sertifikat badan usaha dan $6 \%$ bagi kontraktor yang tidak memiliki sertifikat badan usaha.

Cara Perhitungan PPh Pasal 4 ayat 2 atas Jasa Konstruksi. Setelah menentukan tarif pajak penghasilan pasal 4 ayat 2 atas jasa konstruksi yang akan dipakai untuk perhitungan pajak, maka nilai pajak penghasilan dihitung dengan cara tarif pajak dikalikan dengan dasar pengenaan pajak dari usaha jasa konstruksi. Pajak penghasilan final pasal 4 ayat $2=$ Tarif $\mathrm{x}$ (nilai kontrak atau nilai dari termin pembayaran-PPN atas nilai kontrak atau nilai dari termin tersebut).

Tata Cara Pemotongan PPh Pasal 4 ayat 2 atas Jasa Konstruksi. Berdasarkan PMK (Peraturan Menteri Keuangan) Republik Indonesia Nomor 187/PMK.03/2008 tentang Tata Cara Pemotongan, Penyetoran, Pelaporan, dan Penatausahaan Pajak Penghasilan atas Penghasilan dari Usaha Jasa Konstruksi, PPh final pasal 4 ayat (2) dipotong oleh pengguna jasa pada saat pembayaran jika pengguna jasa merupakan pemotong pajak, atau dipotong dan disetor sendiri oleh penyedia jasa jika pengguna jasa bukan merupakan pemotong pajak. Pemotong pajak yang dimaksud yaitu badan pemerintah, subjek pajak badan dalam negeri, BUT (Bentuk Usaha Tetap), maupun orang pribadi yang dipilih oleh Direktur Jenderal Pajak sebagai pemotong pajak penghasilan. Dengan demikian bendaharawan pemerintah/pimpinan proyek/pimpinan kegiatan yang mengadakan pekerjaan jasa konstruksi wajib memotong pajak penghasilan pasal 4 ayat 2 .

Tata Cara Penyetoran PPh Pasal 4 ayat 2 atas Jasa Konstruksi. Beradasarkan PMK (Peraturan Menteri Keuangan) Republik Indonesia No. 187/PMK.03/2008, tentang Tata Cara Pemotongan, Penyetoran, Pelaporan, dan Penatausahaan Pajak Penghasilan atas Penghasilan dari Usaha Jasa Konstruksi, pajak penghasilan final pasal 4 ayat atas jasa konstruksi penyetorannya dilakukan oleh pengguna jasa apabila statusnya bergerak sebagai pemotong pajak atau disetor sendiri oleh kontraktor selaku pemberi jasa. Untuk menyetorkan pajak penghasilan final pasal 4 ayat 2 atas jasa konstruksi memiliki batas waktu yaitu paling lama harus dilakukan tanggal 10 di bulan berikut setelah bulan terutangnya pajak penghasilan pasal 4 ayat 2 dan tanggal 15 bulan berikutnya sesudah pembayaran diterima oleh pemberi jasa, dan pajak penghasilan pasal 4 ayat 2 yang sudah dipotong selanjutnya disetor ke kantor pos atau bank yang telah ditunjuk oleh Menteri Keuangan, dan penyetoran dilakukan dengan menggunakan surat setoran pajak dan satu surat setoran pajak dipakai saat penyetoran seluruh pajak penghasilan final pasal 4 ayat 2 jasa konstruksi yang telah dipotong di bulan yang bersangkutan. Penyetoran pajak juga bisa dilakukan dengan menggunakan bukti potong lainnya yang setara dengan SSP.

Tata Cara Pelaporan PPh Pasal 4 ayat 2 atas Jasa Konstruksi. Berdasarkan PMK (Peraturan Menteri Keuangan) Republik Indonesia No. 153/PMK.03/2009, batas pelaporan 
pajak penghasilan pasal 4 ayat 2 atas jasa konstruksi yaitu paling lama tanggal 20 di bulan berikut setelah dilakukan pemotongan pajak atau bulan penerimaan pembayaran atas jasa konstruksi dan dilaporkan langsung atau dikirim lewat pos tertulis, namun kalau tanggal 20 itu bertepatan dengan hari libur maka pelaporannya bisa dilakukan saat hari kerja selanjutnya. Sesuai dengan PMK Nomor 243/PMK.03/2014 tentang Surat Pemberitahuan (SPT), pelaporan pajak penghasilan final pasal 4 ayat 2 untuk pengguna jasa maupun pemberi jasa harus menggunakan formulir SPT masa untuk pajak penghasilan final pasal 4 ayat 2 dan dilampiri dengan bukti setoran ke kas negara dan disampaikan ke Kantor Pelayanan Pajak tempat pemotong terdaftar. Yang dimaksud dengan SPT Masa adalah SPT yang digunakan untuk melakukan pelaporan atas pembayaran pajak pada masa tertentu (bulanan). Untuk menghindari terkena sanksi administrasi berupa denda keterlambatan pelaporan, pemotong pajak harus memperhatikan batas waktu pelaporan SPT Masa PPh Pasal final 4 ayat 2. Kelengkapan SPT Masa PPh final pasal 4 ayat 2 juga harus diperhatikan, karena ketika wajib pajak pemotong lupa atau tidak teliti untuk membubuhkan tanda tangan dan melampirkan dokumen yang diperlukan, akan berakibat SPT tersebut dianggap tidak disampaikan.

Jasa Konstruksi. Jasa konstruksi adalah layanan jasa konsultasi perencanaan pekerjaan konstruksi, layanan jasa pelaksanaan pekerjaan konstruksi, dan layanan jasa konsultasi pengawasan pekerjaan konstruksi. Jasa konstruksi memiliki cakupan kegiatan yang cukup luas dimana melibatkan dua pihak yang mengadakan hubungan kerja berdasarkan hukum, yakni pengguna jasa dan penyedia jasa. Pengguna jasa merupakan orang pribadi maupun badan yang masuk dalam bentuk usaha tetap dimana membutuhkan layanan jasa konstruksi, sedangkan penyedia jasa merupakan orang pribadi maupun badan masuk dalam bentuk usaha tetap, dimana kegiatannya merupakan usaha yang menyiapkan layanan jasa konstruksi sebagai perencana konstruksi, pelaksana konstruksi dan pengawas konstruksi.

Kajian Penelitian Terdahulu. Anisah (2015) dalam penelitian yang berjudul analisis perhitungan pajak penghasilan final atas jasa konstruksi pada PT.PLN persero unit induk pem-bangunan 1 medan, bertujuan untuk mengetahui kesesuaian perhitungan pajak penghasilan final atas jasa konstruksi pada PT. PLN unit pembangunan I medan telah sesuai dengan undang-undang nomor 36 tahun 2008 dan PP NO. 40 tahun 2009, dan hasil penelitian menunjukkan bahwa PT. PLN (Pesero) Unit Induk Pembangunan (UIP) I Medan adalah Badan Usaha Milik Negarayang bergerak dibidang ketenaga listrikan dan sebagai pengguna jasa konstruksi yang memungut dan menyetorkan langsung pajak penghasilan final atas jasa konstruksi ke kas negara. Karena adanya perubahan terhadap undang-undang perpajakan dan Peraturan Pemerintah, jadi perlu dilakukan pengarahan dan pengawasan lebih lanjur mengenai sejauh mana peraturan perpajakan telah diterapkan oleh subjek pajak. Persamaan dari penelitian ini yaitu Peneliti sebelumnya melakukan penelitian terhadap pajak penghasilan final atas jasa konstruksi. Perbedaannya yaitu penelitian sebelumnya menggunakan batasan masalah, sedangkan penulis tidak memiliki batasan masalah.

\section{METODE PENELITIAN}

Jenis Penelitian. Jenis penelitian yang digunakan dalam penelitian ini yaitu penelitian kualitatif. Menurut Sugiyono (2013:14) penelitian kualitatif merupakan penelitian yang dipakai pada saaat meneliti keadaan objek yang alamiah, dimana peneliti merupakan instrumen kunci, yang melakukan teknik pengumpulan data secara trianulasi (gabungan), analisis data mempunyai sifat induktif, dan penelitian kualitatifnya memiliki hasil yang lebih menegaskan makna dari pada generalisasi.

Tempat dan Waktu Penelitian. Penelitian ini dilaksanakan pada PT. Realita Timur Perkasa yang beralamat di kompleks Mega Mas Blok B Ruko Mega Smart 2 No. 5, Manado. Proses pengumpulan hingga pengolahan data untuk hasil penelitian ini dimulai pada bulan Mei sampai dengan Juli tahun 2018. 


\section{Jenis, Sumber, dan Metode Pengumpulan Data}

Jenis Data. Data kualitatif dalam penelitian ini adalah data yang berupa penjelasan dari bagian administrasi tentang pemotongan, penyetoran dan pelaporan yang dilakukan oleh bendahara. Data kuantitatif yang digunakan dalam penelitian ini seperti bukti-bukti pemotongan atau pemungutan pajak penghasilan final pasal 4 ayat 2 yang dikenakan atas penghasilan jasa konstruksi.

Sumber Data. Data primer adalah data dari penelitian yang didapat atau yang terkumpul langsung melalui sumber datanya. Untuk memperoleh data primer tersebut, yang meneliti harus memperolehnya secara langsung. Teknik yang dipakai oleh peneliti dalam memperoleh dan mengumpulkan data primer antara lain yaitu observasi, wawancara, dan dokumentasi pada PT. Realita Timur Perkasa.

Metode Pengumpulan Data. Metode pengumpulan data yang digunakan adalah dokumentasi, wawancara, dan observasi.

Metode dan Proses Analisis. Metode analisis yang dipakai dalam penelitian ini yaitu metode analisis deskriptif. Adapun fokus analisis dalam penelitian ini adalah sebagai berikut:

1. Melakukan analisis mengenai perhitungan dan pemotongan PPh final pasal 4 ayat 2 atas jasa konstruksi yang dilakukan PT. Realita Timur Perkasa dengan cara menganalisis data SPM (Surat Perintah Membayar), tujuannya untuk mengetahui apakah perhitungan sudah dilakukan menggunakan tarif yang berdasarkan PP No. 40 tahun 2009, dan pemotongan pajak yang berdasarkan PMK Nomor 153/PMK.03/2009.

2. Melakukan analisis mengenai cara penyetoran pajak penghasilan final pasal 4 ayat 2 yang dilakukan PT. Realita Timur Perkasa, apakah penyetorannya telah memadai berdasarkan PMK Nomor 153/PMK.03/2009.

3. Melakukan analisis mengenai cara pelaporan pajak penghasilan final pasal 4 ayat 2 yang dilakukan PT. Realita Timur Perkasa, apakah pelaporannya sudah berdasarkan PMK No. 153/PMK.03/2009 dalam hal kelengkapan berkas dan ketepatan waktu saat melaporkan pajak penghasilan final pasal 4 ayat 2 atas jasa konstruksi.

\section{HASIL PENELITIAN DAN PEMBAHASAN}

\subsection{Hasil Penelitian}

Ketentuan perpajakan yang diatur dalam Peraturan Pemerintah No. 40 Tahun 2009 yang merupakan perubahan dari Peraturan Pemerintah Nomor 51 tahun 2008 PMK (Peraturan Menteri Keuangan) Republik Indonesia No. 187/PMK.03/2008, usaha jasa konstruksi untuk penghasilannya dikenakan pajak final. Tarif pajak yang dikenakan untuk penghasilan dari usaha jasa konstruksi berbeda sesuai dengan adanya kepemilikkan SBU dan masa berlakunya. Untuk usaha jasa pelaksanaan konstruksi, tarifnya juga dibedakan berdasarkan tingkatan dari kualifikasi kemampuan kontraktor sesuai dengan Peraturan Menteri Pekerjaan Umum Nomor 08/PRT/M/2011 tentang Pembagian Subkalsifikasi dan Subkualifikasi Usaha Jasa Konstruksi.

PT. Realita Timur Perkasa yang bergerak sebagai pelaksana usaha jasa konstruksi ini memiliki Sertifikat Badan Usaha (SBU), yang merupakan tanda bukti pengesahan yang resmi terhadap tingkatan kemampuan usaha yang menyatakan klasifikasi dan kualifikasi usaha atau jenis pekerjaan yang bisa dikerjakan seorang kontraktor yang merupakan subjek pajak. Jadi dalam menentukan tarif pajak yang sesuai dengan ketentuan tarif pajak yang berlaku, perusahaan hanya mengacu pada Sertifikat Badan Usaha (SBU) yang dimiliki, didalamnya menunjukkan bahwa perusahaan ini masuk dalam kualifikasi usaha menengah dan besar atau dikenakan tarif pajak sebesar 3\% dan sudah berdasarkan ketentuan tarif pajak yang berlaku. Setelah menentukan tarif PPh Pasal 4 ayat 2 atas jasa konstruksi yang akan dipakai untuk perhitungan pajak, maka nilai pajak penghasilan dihitung dengan cara tarif pajak dikalikan dengan dasar pengenaan pajak dari usaha jasa konstruksi. 
Perhitungan PPh Pasal 4 ayat 2 atas Jasa Konstruksi. Perhitungan pajak penghasilan final pasal 4 ayat 2 jasa konstruksi diambil dari sampel pada bulan September-Desember 2017, PT. Realita Timur Perkasa mendapatkan proyek dari Satker Bandar Udara Melonguane di Sangir Talaud untuk Pembangunan Bandar Udara Miangas Resa dengan nilai kontrak sebesar Rp9.080.320.000,00 (include PPN dan PPh). Satker Bandar Udara Melonguane membayar harga barang/jasa dari PT. Realita Timur Perkasa berangsur-angsur sesuai dengan kemajuan pekerjaan.

Tabel 1. Daftar pembayaran dan pemotongan pajak atas proyek pelaksanaan konstruksi Bandar Udara Melonguane

\begin{tabular}{|c|c|c|c|c|c|}
\hline Tanggal & Pembayaran & $\begin{array}{c}\text { Nilai Perjanjian } \\
\text { (include PPN) }\end{array}$ & PPN & DPP & $\begin{array}{c}\text { PPh Pasal } 4 \text { ayat } \\
2(3 \%) \\
\end{array}$ \\
\hline $\begin{array}{c}\text { 05 September } \\
2017\end{array}$ & $\begin{array}{l}\text { Angsuran } \\
\text { Nilai } \\
\text { Jaminan }\end{array}$ & Rp1.816.064.000,00 & Rp165.096.727,00 & Rp1.650.967.273,00 & Rp49.529.018,00 \\
\hline $\begin{array}{l}\text { 05 Desember } \\
2017\end{array}$ & $\begin{array}{l}\text { Angsuran } \\
\text { Termin I }\end{array}$ & Rp998.835.200,00 & Rp90.803.200,00 & Rp908.032.000,00 & Rp27.240.960,00 \\
\hline $\begin{array}{l}\text { 05 Desember } \\
2017\end{array}$ & $\begin{array}{l}\text { Angsuran } \\
\text { Termin II }\end{array}$ & Rp1.452.851.200,00 & Rp132.077.382,00 & Rp1.320.773.818,00 & Rp39.623.215,00 \\
\hline $\begin{array}{l}11 \text { Desember } \\
2017\end{array}$ & $\begin{array}{l}\text { Angsuran } \\
\text { Termin III }\end{array}$ & Rp1.452.851.200,00 & Rp132.077.382,00 & Rp1.320.773.818.00 & Rp39.623.215,00 \\
\hline $\begin{array}{l}18 \text { Desember } \\
2017\end{array}$ & $\begin{array}{l}\text { Angsuran } \\
\text { Termin IV }\end{array}$ & Rp1.452.851.200,00 & Rp132.077.382,00 & Rp1.320.773.818.00 & Rp39.623.215,00 \\
\hline $\begin{array}{l}18 \text { Desember } \\
2017\end{array}$ & $\begin{array}{l}\text { Angsuran } \\
\text { Termin V }\end{array}$ & Rp1.452.851.200,00 & Rp132.077.382,00 & Rp1.320.773.818.00 & Rp39.623.215,00 \\
\hline $\begin{array}{l}21 \text { Desember } \\
2017\end{array}$ & $\begin{array}{l}\text { Pelunasan } \\
\text { Termin } \\
\text { Retensi I }\end{array}$ & Rp454.016.000,00 & Rp41.274.181,00 & Rp412.741,818,00 & Rp12.382.255,00 \\
\hline \multicolumn{2}{|c|}{ JUMLAH } & Rp9.080.320.000,00 & Rp825.483.636,00 & Rp8.254.836.363,00 & Rp247.645.093,00 \\
\hline
\end{tabular}

Sumber: PT. Realita Timur Perkasa

Pemotongan PPh Pasal 4 ayat 2 atas Jasa Konstruksi. Apabila pengguna jasa adalah seorang pemotong pajak, maka pengguna jasa konstruksi melakukan pemotongan pajak pada saat pembayaran, atau di potong sendiri oleh penyedia jasa atau PT. Realita Timur Perkasa. Yang dimaksud dengan pemotong pajak adalah badan pemerintah, subjek pajak badan dalam negeri, bentuk usaha tetap, atau orang pribadi yang ditunjuk oleh Direktur Jenderal Pajak sebagai pemotong pajak penghasilan. Sebagai bukti bahwa Bendaharawan sudah memotong dan menyetorkan PPh Pasal 4 ayat 2 maka harus memberikan bukti pemotongan/pemungutan $\mathrm{PPh}$ Pasal 4 ayat 2 atas penghasilan dari jasa konstruksi, dan surat setoran pajak. Dengan demikian, bendaharawan pemerintah/pimpinan proyek/pimpinan kegiatan yang mengadakan pekerjaan jasa konstruksi wajib melakukan pemotongan $\mathrm{PPh}$ Pasal 4 ayat 2 . 
Tabel 2. Daftar pemotongan pajak atas pelaksanaan konstruksi PT. Realita Timur Perkasa periode 1 Januari - 31 Desember 2017

\begin{tabular}{|c|c|c|c|c|c|c|}
\hline Tanggal & $\begin{array}{c}\text { Nama } \\
\text { Proyek }\end{array}$ & Pendapatan Bruto & DPP & Pendapatan Neto & PPN & $\begin{array}{c}\text { PPh Pasal } 4 \text { ayat } 2 \\
\text { tarif } 3 \%\end{array}$ \\
\hline $\begin{array}{l}26 \text { Mei } 2017 \\
\text { sampai } \\
\text { 30 Desember } \\
2017\end{array}$ & $\begin{array}{l}\text { Pembangunan } \\
\text { Faspel Laut } \\
\text { Kuala } \\
\text { Mendahara }\end{array}$ & Rp13.378.912.000,00 & Rp12.162.647.273,00 & Rp11.797.767.854,00 & Rp1.216.264.727,00 & Rp364.879.418,00 \\
\hline $\begin{array}{l}22 \text { Maret } \\
2017 \\
\text { samnai }\end{array}$ & $\begin{array}{l}\text { Preservasi } \\
\text { Rekonstruksi } \\
\text { KSLialan }\end{array}$ & Rp34.135.019.000,00 & Rp31.031.835.454,00 & Rp30.100.880.390,00 & Rp3.103.183.545,00 & Rp930.955.063,00 \\
\hline $\begin{array}{l}29 \text { Desember } \\
2017\end{array}$ & $\begin{array}{l}\text { Onggunoi } \\
\text { Pinolosian } \\
\text { Molibagu }\end{array}$ & & & & & \\
\hline $\begin{array}{c}\text { 05 September } \\
2017 \\
\text { Sampai } \\
\text { 30 Desember } \\
2017\end{array}$ & $\begin{array}{l}\text { Pembangunan } \\
\text { Bandar Udara } \\
\text { Miangas Resa }\end{array}$ & Rp9.080.320.000,00 & Rp8.254.836.365,00 & Rp8.007.191.272,00 & Rp825.483.636,00 & Rp247.645.090,00 \\
\hline Jumlah & & Rp56.594.251.000,00 & Rp51.449.319.092,00 & Rp49.905.839.516,00 & Rp5.144.931.908,00 & Rp1.543.479.571,00 \\
\hline
\end{tabular}

Sumber: PT. Realita Timur Perkasa

Penyetoran PPh Pasal 4 ayat 2 atas Jasa Konstruksi. Pajak penghasilan final pasal 4 ayat atas jasa konstruksi penyetorannya dilakukan oleh pengguna jasa apabila statusnya bergerak sebagai pemotong pajak. Tapi, apabila pengguna jasa tidak berstatus sebagai pemotong pajak, maka kontraktor sebagai pemberi jasa dan penerima penghasilan, harus menyetor sendiri pajak terutangnya. Penyetoran pajak penghasilan final pasal 4 ayat 2 atas jasa konstruksi memiliki batas waktu yaitu paling lama harus dilakukan tanggal 10 di bulan berikut setelah terutangnya pajak penghasilan pasal 4 ayat 2 dan tanggal 15 di bulan berikut sesudah diterimanya pembayaran oleh pemberi jasa. Pemenuhan kewajiban perpajakan dalam hal ini menyetorkan pajak penghasilan pasal 4 ayat 2 atas jasa konstruksi, PT. Realita Timur Perkasa tidak melaksanakan kewajiban perpajakan dalam hal ini menyetor pajak penghasilan final pasal 4 ayat 2, karena sudah dilaksanakan oleh bendaharawan pemerintah atau bendahara pemotong yang dalam hal ini merupakan pengguna jasa atau sebagai pihak pembeli. Saat ini pembayaran $\mathrm{PPh}$ pasal 4 ayat 2 telah beralih dari pembayaran manual ke sistem pembayaran pajak secara online melalui e-billing. Setelah dilakukan pembayaran atau penyetoran $\mathrm{PPh}$ Pasal 4 ayat 2, maka didapatlah bukti pembayaaran yang divalidasi bank yang didalamnya terdapat Nomor Transaksi Penerimaan Negara (NTPN) sebagai bukti bahwa PPh Terutang telah dibayarkan ke Kas Negara. Untuk PT. Realita Timur Perkasa hanya menerima SPM (Surat Perintah Membayar) yang didalamnya sudah ada keterangan mengenai pemotongan PPh dan PPN yang sudah dilakukan bendahara pemotong. Jadi perusahaan PT. Realita Timur Perkasa sudah tidak lagi menyetor PPh Pasal 4 ayat 2.

Pelaporan PPh Pasal 4 ayat 2 atas Jasa Konstruksi. Setelah melakukan kewajiban perpajakan yaitu pemotongan dan pembayaran, maka akan memperoleh bukti potong atau bukti pembayaran dari bendaharawan pemotong atau pengguna jasa berupa Surat Perintah Membayar (SPM), maka selanjutnya tinggal melaksanakan kewajiban perpajakan dalam hal ini melaporkan PPh Pasal 4 ayat 2 dan semua transaksi pemotongan pajak harus diisi pada SPT Masa PPh Pasal 4 ayat 2 yang sekarang sudah menggunakan aplikasi e-SPT PPh Pasal 4 ayat 2 dan setelah itu dilaporkan ke Kantor Pelayanan Pajak dengan melengkapi dokumen atas pekerjaan untuk pelaporan pajak apakah cocok dengan pemotongan yang sudah dilakukan.

\subsection{Hasil Pembahasan}

Analisis Perhitungan dan Pemotongan PPh Final Pasal 4 ayat 2 atas Jasa Konstruksi di PT. Realita Timur Perkasa. Dari hasil penelitian terhadap PT. Realita Timur Perkasa, tentang Pajak penghasilan atas penghasilan dari usaha jasa konstruksi, perusahaan ini telah melakukan kewajiban perpajakannya yaitu pajak penghasilan final pasal 4 ayat 2 jasa konstruksi. Penerapan pajak penghasilan final pasal 4 ayat 2 atas jasa konstruksi pada 
PT. Realita Timur Perkasa dalam hal perhitungan dan pemotongan dianalisis dengan menggunakan data SPM (Surat Perintah Membayar). Dalam SPM ini menggambarkan jumlah nilai kontrak, pendapatan yang diterima perusahaan, banyaknya pajak penghasilan final pasal 4 ayat 2 dan pemotongan PPN keluaran. Di SPM ini juga disebutkan jenis pekerjaan apa yang dilakukan perusahaan dan pada tanggal berapa pendapatan tersebut diterima. Data SPM yang diberikan oleh pihak perusahaan inilah penulis mendapatkan data mengenai perhitungan dan pemotongan pajak jasa konstruksi yang dipotong dari pendapatan PT. Realita Timur Perkasa di bidang jasa konstruksi. Pendapatan PT. Realita Timur Perkasa langsung dikenai tarif pajak yaitu 3\% sesuai SIUJK masuk kualifikasi usaha besar dan menengah. Dalam memotong PPh final pasal 4 ayat 2 atas usaha dari jasa konstruksi dilaksanakan oleh penerima jasa pada waktu melakukan pembayaran apabila pengguna jasa sebagai pemotong pajak, atau di potong sendiri oleh PT. Realita Timur Perkasa jika pengguna jasa bukan pemotong pajak. Dilihat dari uraian tersebut mengenai pengenaan tarif, perhitungan, serta pemotongan pajak penghasilan final yang dilakukan oleh PT. Realita Timur Perkasa jika dibandingkan dengan Peraturan Pemerintah Nomor 40 Tahun 2009 dan Peraturan Menteri Keuangan Republik Nomor 153/PMK.03/2009, maka dapat dikatakan dalam hal pengenaan tarif, perhitungan, serta pemotongan pajak penghasilan final jasa konstruksi, PT. Realita Timur Perkasa sudah sesuai dengan ketentuan yang berlaku.

Analisis Penyetoran PPh Final Pasal 4 ayat 2 atas Jasa Konstruksi di PT. Realita Timur Perkasa. PPh Pasal 4 ayat 2 yang sudah dipotong selanjutnya disetor ke kantor pos atau bank yang telah ditunjuk oleh Menteri Keuangan. Untuk penyetoran pajak penghasilan final pasal 4 ayat 2 PT. Realita Timur Perkasa tidak lagi menyetor pajak penghasilan final pasal 4 ayat 2, karena pengguna jasa mempunyai status yaitu pemotong pajak, maka pajak penghasilan dilunaskan lewat potongan pajak penghasilan dari pengguna jasa. Tapi, apabila pengguna jasa tidak berstatus sebagai pemotong pajak, maka PT. Realita Timur Perkasa sebagai pemberi dan penerima penghasilan akan menyetor sendiri pajak penghasilan terutangnya sesuai dengan ketentuan batas waktu yang ditentukan dan untuk penyetoran sekarang tidak lagi menggunakan Surat Setoran Pajak (SSP), namun untuk pembayaran masa pajak telah menggunakan sistem e-billing. Dari uraian diatas, jika dibandingkan dengan Peraturan Pemerintah Nomor 40 Tahun 2009 dan Peraturan Menteri Keuangan Nomor 153/PMK.03/2009, maka penyetoran PPh final pasal 4 ayat 2 atas jasa konstruksi yang dilakukan oleh PT. Realita Timur Perkasa dapat dikatakan sudah sesuai dengan ketentuan yang berlaku.

Analisis Pelaporan PPh Final Pasal 4 ayat 2 atas Jasa Konstruksi di PT. Realita Timur Perkasa. Dalam memenuhi kewajiban pelaporan pajak ini, PT. Realita Timur Perkasa sering mengalami kendala yang di akibatkan oleh pihak pengguna jasa atau pihak pembeli, dimana sering adanya keterlambatan dalam memberikan dokumen-dokumen yang akan digunakan atau dilampirkan di SPT Masa jadi dengan begitu PT. Realita Timur Perkasa sering terlambat melakukan pelaporan SPT Masa dan bahkan PT. Realita Timur Perkasa juga sering tidak melakukan pelaporan PPh pasal 4 ayat 2 atas jasa konstruksi yang dipotong dengan alasan karena jenis pajak tersebut adalah final maka tidak perlu lagi dilakukan pelaporan. Hal ini jika dibandingkan dengan ketentuan pada Peraturan Pemerintah No. 40 Tahun 2009 dan PMK (Peraturan Menteri Keuangan) No. 243/PMK.03/2014, bahwa SPT Masa PPh Pasal 4 ayat 2 bersama dengan lampiran wajib dilaporkan ke Kantor Pelayanan Pajak paling lama tanggal 20 bulan berikutnya dan langsung dikirim melalui pos tertulis. Tapi apabila tanggal 20 jatuh di hari libur, maka bisa dilaporkan pada hari kerja selanjutnya. Jika tidak dilaporkan maka akan diberikan sanksi administrasi atau denda sebesar Rp100.000,00. Maka dapat dikatakan bahwa dalam melaporkan pajak penghasilan final pasal 4 ayat 2, PT. Realita Timur Perkasa belum sesuai dengan peraturan yang sudah ditetapkan. 


\section{KESIMPULAN DAN SARAN}

\subsection{Kesimpulan}

Berdasarkan pembahasan dari hasil penelitian terhadap pajak penghasilan final pasal 4 ayat 2 atas jasa konstruksi pada PT. Realita Timur Perkasa, maka dapat disimpulkan sebagai berikut :

1. Perhitungan pajak penghasilan final pasal 4 ayat 2 jasa konstruksi di PT. Realita Timur Perkasa sudah sesuai dengan ketentuan PP No. 40 Tahun 2009 dan PMK No. 153/PMK.03/2009, dengan menggunakan tarif sebesar 3\% dengan kualifikasi usaha besar dan menengah. Nilai pajak penghasilan dihitung dengan mengalikan tarif dengan Dasar Pengenaan Pajak (DPP) dari usaha jasa konstruksi.

2. Pemotongan pajak penghasilan final pasal 4 ayat 2 jasa konstruksi yang dilaksanakan oleh PT. Realita Timur Perkasa sudah sesuai dengan ketentuan PP No. 40 Tahun 2009 dan PMK No. 153/PMK.03/2009, karena pajak penghasilan final pasal 4 ayat 2 atas jasa konstruksi dipotong pengguna jasa pada saat melakukan pembayaran apabila pengguna jasa dalam hal ini merupakan pemotong pajak, atau di potong sendiri oleh PT. Realita Timur Perkasa jika pengguna jasa bukan pemotong pajak.

3. PT. Realita Timur tidak lagi menyetorkan pajak penghasilan final pasal 4 ayat 2 , karena pengguna jasa berstatus sebagai pemotong pajak, maka penyetoran dan pelunasan $\mathrm{PPh}$ dilakukan oleh pengguna jasa. Namun, apabila pengguna jasa bukan sebagai pemotong PPh, maka PT. Realita Timur Perkasa selaku pemberi jasa dan penerima penghasilan akan menyetorkan $\mathrm{PPh}$ yang terutang sesuai dengan ketentuan batas waktu yang ditentukan. Dan untuk penyetoran sekarang tidak lagi menggunakan Surat Setoran Pajak (SSP), namun untuk pembayaran masa pajak telah menggunakan sistem e-billing. Jadi untuk penyetoran PPh Pasal 4 ayat 2 atas jasa konstruksi yang dilakukan PT. Realita TImur Perkasa sudah sesuai dengan ketentuan PP (Peraturan Pemerintah) No. 40 Tahun 2009 dan PMK No. 153/PMK.03/2009.

4. Dalam melaporkan pajak penghasilan pasal 4 ayat 2 atas jasa konstruksi pada PT. Realita Timur Perkasa belum sesuai dengan PP Nomor 40 Tahun 2009 dan PMK Nomor 153/PMK.03/2009, karena sering adanya keterlambatan dokumen-dokumen untuk dilampirkan di SPT Masa yang disebabkan oleh pihak pengguna jasa atau pemotong pajak dan bahkan terkadang tidak melakukan pelaporan PPh Pasal 4 ayat 2 yang dipotong dengan alasan bahwa jenis pajak tersebut adalah final, maka tidak perlu lagi dilakukan pelaporan.

\subsection{Saran}

Berdasarkan penelitian yang dilakukan ini, penulis menyarankan agar PT. Realita Timur Perkasa harus lebih memperhatikan ketentuan perpajakan dalam hal ini perhitungan, pemotongan, penyetoran, dan pelaporan PPh Pasal 4 ayat 2 atas jasa konstruksi agar dapat terlaksana berdasarkan peraturan perpajakan yang sudah ditetapkan, dan harus mempertahankan ketaatan dalam hal kewajiban perpajakan yang telah dilaksanakan dan dijaga selama ini agar dapat terhindar dari sanksi pajak sudah ditetapkan yang bisa saja terjadi. Penulis juga memberikan saran kepada PT. Realita Timur Perkasa agar dapat lebih mempertegas lagi dan terus mengingatkan kepada pihak pengguna jasa dalam hal ini sebagai pemotong pajak agar supaya tidak terlambat lagi memberikan dokumen-dokumen atau buktibukti pemotongan PPh Pasa 4 ayat 2 yang akan dilampirkan di SPT Masa, sehingga tidak akan terjadi lagi keterlambatan pelaporan pajak, dan harus melaporkan pemotongan pajaknya agar tidak terkena sanski administrasi. 


\section{DAFTAR PUSTAKA}

Agoes, S. dan E. Trisnawati. 2009. Akuntansi Perpajakan. Edisi 2 Revisi. Salemba Empat. Jakarta.

Anisah, J. 2015. Analisis Perhitungan Pajak Penghasilan final atas jasa Konstruksi pada PT.PLN (Persero) Unit Induk Pembangunan (UIP) 1 Medan. Skripsi program studi akuntansi Politeknik Negeri Medan. Medan.

Hendra. 2014. Penerapan Akuntansi Pajak Penghasilan Pasal 23 pada PT. Golden Mitra Inti Perkasa. Jurnal EMBA. Vol. 2 No. 1. ISSN 2303-1174.

Hakim, F. 2015. Analisis Penerapan PP. No.46 Tahun 2013 Tentang Pajak Penghasilan UMKM Terhadap Tingkat Pertumbuhan Wajib Pajak Dan Penerimaan PPh Pasal 4 Ayat (2) Pada KPP Pratama Manado. Jurnal EMBA Vol.3 No.1 ISSN 2303-1174.

Mardiasmo. 2018. Perpajakan Edisi Terbaru. Jakarta Andi. Yogyakarta.

Peraturan Pemerintah Nomor 40 Tahun 2009 Pajak Penghasilan atas Penghasilan dari Usaha Jasa Konstruksi. Lembaran Negara Republik Indonesia Tahun 2009 Nomor 5014. Jakarta.

Peraturan Menteri Keuangan Nomor.153/PMK.03/2009 Tata Cara Pembayaran dan Penyetoran Pajak.

Peraturan Menteri Keuangan Nomor.243/PMK.03/2014 Surat Pemberitahuan (SPT).

Peraturan Menteri Pekerjaan Umum Nomor 08/PRT/M/2011 Pembagian Subkalsifikasi dan Subkualifikasi Usaha Jasa Konstruksi.

Sugiyono. 2013. Metode Penelitian Bisnis. Alfabeta. Bandung.

Undang-Undang Republik Indonesia Nomor 36 Tahun 2008 Perubahan Keempat Atas Undang-Undang Nomor 7 Tahun 1983 Tentang Pajak Penghasilan. Lembaran Negara Republik Indonesia Tahun 2008 Nomor 4893. Jakarta.

Watung, L.R. 2016. Analisis Penerapan Pajak Dengan Withholding Tax System terhadap Pajak Penghasilan Pasal 4 Ayat 2 Pada PT. Bank Sulutgo Di Kota Manado. Jurnal Emba Vol.4 No.1. Issn 2303-1174. 